IFN Working Paper No. 865, 2011

\title{
Employment Consequences of Employment Protection Legislation
}

Per Skedinger 


\title{
Employment consequences of employment protection legislation*
}

\author{
Per Skedinger**
}

March 11, 2011

\begin{abstract}
Summary
This article surveys the literature and adds to the evidence on the impact of employment protection legislation on employment. While stringent employment protection contributes to less turnover and job reallocation, the effects on aggregate employment and unemployment over the business cycle are more uncertain.

Exploitation of partial reforms and the use of micro data in recent research appear not to have affected results regarding employment and unemployment in any systematic way. Labour market prospects of young people and other marginal groups seem to worsen as a consequence of increased stringency of the legislation. It is debatable whether marginal groups have gained much from the widespread policy strategy to liberalize regulations of temporary employment and leave regulations of regular employment intact. My own analysis suggests that increased stringency of regulations for regular work is associated with a higher incidence of involuntary temporary employment, particularly among the young.
\end{abstract}

Keywords: Job security, employment effects, employment protection reforms JEL Classification Numbers: J23, J5, K31

\footnotetext{
${ }^{*}$ I thank Bertil Holmlund for useful comments, Aron Berg for able research assistance and the Jan Wallander and Tom Hedelius Research Foundation for generous financial support.

${ }^{* * *}$ Research Institute of Industrial Economics, per.skedinger@ifn.se
} 
Two decades have elapsed since Edward Lazear's seminal cross-country study on the employment effects of employment protection legislation (Lazear, 1990). Since then the measurement of the stringency of legislation has improved in several ways: from narrow indices to more comprehensive ones, from coverage of few countries to larger selections and from time-invariant measures to incorporation of annual frequency data. In addition, the use of micro data has become widespread, in contrast to the earlier literature which was largely based on aggregate data.

A relatively recent development in the research is the exploitation of partial employment protection reforms within countries. By the design of such reforms, suitable control groups arise naturally inasmuch as certain firms or groups on the labor market are not subject to the reforms, thereby minimizing the dependency on possibly mismeasured indices.

All in all, these developments give more opportunity for reliable identification of the true employment consequences of employment protection legislation. Yet, employment protection legislation remains a complex and controversial institution, whose employment effects continue to elude researchers.

The purpose of this article is to survey and discuss the ever-expanding literature on employment effects of employment protection legislation. This research includes studies on the level of employment and unemployment and their distribution across demographic groups, personnel turnover and job reallocation. ${ }^{1}$ The article also describes the design of employment protection across countries, its evolution over time and adds to the empirical evidence concerning its effects.

Not only has employment protection become an important topic in the institutional approach to labour markets, these markets have also changed in ways that make questions of employment protection more pressing than before. Increased globalization and rapid technological innovation place demands on the ability to adapt for both businesses and employees while, at the same time, there is a legitimate need for a safety net for those workers who are adversely affected by the changes. Moreover, the challenges of the recent worldwide recession have brought employment protection issues to the forefront on the policymaking agenda and they are likely to remain there for years to come.

\footnotetext{
${ }^{1}$ For a recent survey that also includes studies dealing with effects on wages, firm dynamics, growth, productivity, sickness absence, perceived job security and psychological well-being, see Skedinger (2010).
} 
In order to provide a background to the empirical research, Section 2 contains a brief discussion of theoretical work and Section 3 describes the design and evolution of employment protection legislation in industrialized countries. The regulation typically imposes limitations on the employer's ability to fire employees and use temporary workers. The single most important element in the legislation is the definition of "unfair" dismissal (or dismissal without "just cause") and the penalties imposed on employers for such dismissals. There are great differences across countries in the strictness of their regulations and these differences seem to be relatively constant over time - but there has been a tendency towards convergence in stringency since the 1980s. Many European countries have liberalized the regulation of temporary contracts, while leaving the regulation of permanent jobs basically unchanged. This section also discusses the degree to which regulations are differentiated regarding various kinds of firms or groups within the labour market. Some countries, like Sweden, have far-ranging optional laws, allowing parts of the regulation to be set aside by mutual consent of employers and unions. An important issue is to figure out to what extent available measures of employment protection capture the apparent complexity of legislation. Section 3 also contains an analysis of involuntary temporary employment and its determinants.

The empirical literature is discussed extensively in Section 4. The presentation is organized according to the manner in which the studies were set up: Cross-country analyses with aggregate data, cross-country-studies with disaggregate data and withincountry studies. About half of the studies are from the last few years, a development which reflects the increasing interest among researchers in issues related to employment protection.

The concluding section discusses what we have learned from the research so far and tries to assess its implications from the perspective of the recent financial crisis. What effects can we expect that the employment protection regulations have had during the crisis - and will have, during its aftermath? The bulk of the present regulation of permanent work in most European countries was created many decades ago, when the labour market was substantially different. What does the research have to say about the optimal design of employment protection legislation and is there a best way forward for reforming it? 


\section{What are the conceivable employment effects of employment protection legislation?}

Firing costs do not only decrease the employer's inclination to lay off an employee, but also his or her willingness to hire new recruits. The latter effect is due to the fact that the firm incorporates potential future costs in the case of a lay-off already in the hiring decision. With higher firing costs, greater uncertainty regarding the factors which determine the size of the work force will make the company more reluctant to hire someone. For instance, it can be difficult to determine in advance how a new employee will fit into a work group or an organization and how this employee will manage the company's routines, especially if the employee in question lacks earlier work experience.

Taken together, the effects of a more stringent employment protection thus imply that employee turnover is reduced, since the flows into and out of the firms are smaller. One consequence of this is that average job tenures and unemployment durations are longer than in countries or sectors with less employment protection. Hence, the net effect on employment and unemployment is theoretically indeterminate and depends upon which of the two flows dominates (Bertola, 1999).

Another theoretical prediction is that employment protection will dampen swings in employment and unemployment over the business cycle. During a downturn, fewer employees are fired with stringent employment protection, while during an upturn, not as many employees are hired. The various stages in the business cycle can in themselves exert an influence on the uncertainty factors associated with hirings, which reinforces a disinclination to hire during economic lows. Lindbeck's (1993) analysis points to the possibility that employment protection has different effects depending on the stage of the business cycle and that unemployment can become permanent after a deep recession. Firms may become reluctant to take on new employees since they are uncertain as to how long the recovery will last. There are also some hypotheses which state that stringent employment protection has more negative effects on employment after macroeconomic shocks (Blanchard and Wolfers, 2000).

Employment protection can also influence the composition of the employed and the unemployed at given levels of employment and unemployment (Bertola et al., 2007). In principle, the same fundamental mechanisms should be at work for all 
groups in the labour market, namely that both the likelihood of being fired and being hired is reduced. However, employment protection is usually designed in a manner that can influence different groups in different ways (as discussed in Section 2). Periods of notice and severance pay usually rise with longer tenure, which raises the risk of lay-off for individuals with short tenure. Vulnerable groups in the labour force are often overrepresented among those with short tenure. In certain countries, there are also legislated seniority rules. A rationale for differentiation according to age is that young individuals have a smaller opportunity cost than older individuals for not being employed, for example, when taking part in education (Belot et al., 2007).

Furthermore, uncertainty concerning a potential employee's productivity ought to be more explicit for groups with limited work experience or where the qualifications are not as easily verifiable as those of other groups (for instance, among immigrants with foreign education). Taken together, these factors speak for the possibility that vulnerable groups in the labour force, such as youth, immigrants, longterm unemployed and those with disabilities, are negatively affected by employment protection compared to other groups.

Up to now, the discussion has not considered the possibility that wages can be affected by employment protection. The effects on wages are ambiguous, however. On the one hand, wages can be reduced if employers demand compensation for higher firing costs (Lazear, 1990). In this case, it is far from certain that the total costs for an employer increase with employment protection legislation. If total costs do not increase, then employment is not affected either. ${ }^{2}$ Collective agreements and minimum wages, however, can hinder wage adjustment to lower levels. According to some theories, there may also be an interaction between employment protection and other labour market institutions which influences wage flexibility.

On the other hand, wages can rise as a consequence of employment protection, to the extent that the bargaining power of employees is increased relative to that of employers. Higher firing costs can create a group of so-called insiders within the company (Lindbeck and Snower, 2001). These people can have a relatively protected position, both in relation to other employees, who might have, for example, temporary jobs, and to those outside the firm who might be willing to work for a lower wage

\footnotetext{
${ }^{2}$ It should be noted that if employers incur firing costs in excess of benefits accruing to workers, in the form of red tape and legal costs, these additional costs may be detrimental to employment (Burda, 1992).
} 
than what the insiders receive. Certain components in employment protection legislation, such as notification times, severance pay and seniority rules, can improve the position of insiders and therefore drive up their wages. Wage inflation due to increased bargaining power of insiders should contribute to lower employment and higher unemployment. To the extent that employment protection reduces the probability of finding a job in case an insider is actually laid off, there is, however, also an opposing effect that serves to reduce wage pressure.

A common reform strategy in Europe has been to liberalize the rules for temporary employment, but to leave the regulation for permanent employment intact (further discussed in Section 2). According to Blanchard and Landier (2002) and Cahuc and Postel-Vinay (2002), such policies can have negative consequences. Employers can be induced to fire temporary employees even if they are productive, since otherwise they would become permanently employed insiders, with higher firing costs. This can lead to an excess of employee turnover and increased unemployment, which can undermine the advantages gained through increased flexibility for the firms.

\section{The design and evolution of employment protection legislation}

Employment protection legislation covers three main areas: Regular employment, temporary employment and collective dismissals. Regulation regarding regular work deals with the definition of just cause for dismissal, time limits for notification, severance pay and other procedural rules in connection with dismissals. Further restrictions, such as notice to a union or public employment service, may apply if a dismissal is defined as collective. Temporary work is regulated by time limits and valid reasons for fixed-term contracts and by defining which kinds of work can be used from temporary work agencies.

\subsection{Evolution over time}

One way of getting a summary view of the strictness of the legislation is to construct an index, that is, a measure that considers the legislation in its entirety by assigning weights to its various components. The OECD has constructed the most comprehensive index in this respect. This index considers regulations within the main 
areas of regular employment, temporary employment and collective dismissals. The index has a round number scale between 0 and 6 , where the highest number represents the most stringent legislation. The OECD has updated and enlarged its index continuously since the 1990s, both with regard to the components of the index and the number of countries included. The latest version refers to the conditions of the year 2008 and includes, besides the OECD countries, a selection of developing countries and transition economies.

Figure 1 depicts the development of employment protection during the period 1950-2008 in various groups of OECD countries. This figure is based on Allard's (2005) extension backwards in time of the OECD's (2004) index for specific countries up to 1998 and on the OECD index for 1998-2008. As the series constructed by Allard excludes some components in the legislation that are considered by the OECD, figures for the two periods are not exactly comparable (as indicated by a vertical line in the figure). I have aggregated the countries into four groups, where the countries in each group have roughly similar levels of employment protection.

The four groups of countries in Figure 1 are Southern Europe, the Nordic countries, Continental Europe and the Anglo-Saxon countries. The stringency of employment protection varies greatly among many of the country groups and it has increased overall since 1950. However, the level of employment protection has remained more stable since the beginning of the 1980s. ${ }^{3}$ In 2008 the average index of the six level scale ranged between 1.1 (Anglo-Saxon countries) and 2.8 (Southern Europe), whereas the Nordic countries and Continental Europe show a similar level of employment protection (at about 2.2). There are tendencies towards convergence; since the beginning of the 1990s, legislation has become more liberal, especially in Southern Europe and the Nordic countries, while employment protection in the Anglo-Saxon countries has become somewhat stronger compared to the mid-1980s. Otherwise, the predominant impression is that the differences between the groups of countries are strikingly robust.

Figure 2 shows unemployment levels in the same country aggregates during the period 1960-2009. As in the previous figure, a trend increase is noted up until the

\footnotetext{
${ }^{3}$ This development may be contrasted to the deregulation of product markets, where the value of the relevant index has declined from around 5 to around 2 for 21 OECD countries during the period 1980 2003 (OECD, 2006).
} 
1990s, with the exception of Anglo-Saxon countries where the rising trend is broken already at the beginning of the 1980s. Unemployment has usually been higher in Southern Europe than in the other groups. Excluding a short period during the 1990s, the Nordic countries have had low unemployment compared to other countries. The Anglo-Saxon countries show a relatively high unemployment rate during much of the period considered, but since the mid-1990s, they have had a lower unemployment rate than the other groups of countries. With the onset of the financial crisis, there is a palpable increase in unemployment in all country groups in 2009.

Observations such as those in Figures 1 and 2 have prompted a discussion among researchers regarding to what degree increased unemployment in Europe can be explained by stringent employment protection. A certain correlation, although far from perfect, between levels of employment protection and unemployment can certainly be drawn from the two figures. The question of possible cause and effect is complicated, however, since, among other things, employment protection became stricter at least a decade before the strong rise in unemployment took place in the mid1970s. It can also be noted that during the crisis year 2009, unemployment shot up the most in Southern Europe and the Anglo-Saxon countries, and with about as much in percentage terms, despite the two country groups having quite different levels of employment protection.

How stringent is employment protection in individual OECD countries? Table 1 shows both the OECD's summary index and its separate indices for regular employment, temporary employment and collective dismissals. The information refers to 2008 and includes, in addition to the "old" OECD countries in Figures 1 and 2, Japan and the new member countries in Eastern Europe, Asia and Latin America.

The United States, Great Britain and Canada have the least stringent legislation according to the summary index (ranging between 0.9 and 1.1), while Turkey, Luxembourg, Mexico, Spain and Greece have the most extensive (3.0-3.5). An important change in American legislation since the 1980s is that an increasing number of states have introduced the possibility for employees of having the question of just cause for dismissal tried in court. Even considering these changes as more restrictive, the United States is still the country ranked as the most liberal by the OECD as far as employment protection is concerned. 
Among the Nordic countries, Denmark stands out with less stringent employment protection than its neighbours. Denmark is usually put forward as the prime example of the much-heralded flexicurity model, which combines flexible hiring and firing rules with generous unemployment benefits. However, it is difficult to attribute the relatively low unemployment rate in Denmark since the 1990s to the flexicurity model, since the country experienced much higher unemployment in the 1970s and 1980s with basically the same employment protection legislation (Andersen and Svarer, 2007).

In Figure 1, it could be noted that legislation has been somewhat liberalized in some of the groups of OECD countries since the 1980s. Liberalization has not been equally distributed across the three main areas of legislation, however, but has almost exclusively been related to rules for temporary employment. In Figure $3 \mathrm{a}$, the strictness of legislation regarding temporary employment in 2008 (the vertical axis) is compared to the conditions during 1990 (the horizontal axis). In the lower half of the figure, countries which have liberalized their regulations during this period are shown, and most of the observations are found in this half. Italy and Sweden are among the countries with the sharpest reduction in the stringency of regulation. Among important reforms in Sweden during the period were the legalization of temporary work agencies in 1993 and the introduction of the "general fixed-term employment" contract in 2007, which allowed temporary work for any reason and up to 24 months within a period of five years with the same employer. ${ }^{4}$

In contrast, the corresponding figure for regular employment (Figure 3b) displays a cluster of countries on or close to the 45-degree line, which means that no or very modest reforms have been undertaken. Portugal and Spain stand out as exceptions. In Portugal, a reform of dismissal regulations in 2009 involved, among other things, reductions in the delay before a notice periods starts and reduced notice periods for workers with short tenure. The reform was achieved with complementary reforms in social policy. In Spain, the definition of just cause for dismissal was widened in 1994 and the firing costs for certain groups of permanent employees were reduced in 1997.

A possible explanation for the fact that reforms were undertaken in so many parts of Europe may be that the legislation regarding employment protection, rightly

\footnotetext{
${ }^{4}$ Cahuc (2010) provides a detailed discussion of employment protection reforms undertaken in Sweden.
} 
or wrongly, was understood as a contributing reason for a persistently high unemployment rate, which led to political pressure to bring about change. The fact that the reform strategies were so one-sidedly biased vis-à-vis the terms of temporary employment contracts can be due to political pressure from the noticeably larger and more well-organized groups with permanent employment.

\subsection{Are all equal before the law?}

One shortcoming of available indices on employment protection is that they are only constructed for a "typical worker" and provide little or no information about the coverage of the legislation, for example, to what extent regulations differ for different types of firms or workers. ${ }^{5}$ This means that the picture of employment protection is far from complete.

A potentially important omission in this respect is that information is lacking about the extent to which small firms are exempted from employment protection legislation. One rationale for having more liberal rules for small firms is that these firms are more sensitive to the cost-increasing effects of employment protection than larger firms. This may be due to fixed costs of employment protection being divided among fewer employees and a smaller potential for spreading risks. There may also be reasons for not exempting small firms, for example, if the growth of small firms is impeded due to incentives not to cross the size threshold where exemptions do not apply, or if it is believed that the special interests of small firms are already provided for in the actual implementation of the legislation by the courts (as has been argued in the Swedish case by Ahlberg et al., 2006).

Exemptions from employment protection legislation for small firms are widespread in OECD countries, but the size threshold varies across countries as does the extent to which small firms are exempt. Details on exemptions for small firms in 19 OECD countries are reported by Venn (2009). The number of workers affected by the exemptions, as a share of total employment, varies from 20 per cent in Korea to more than half in Australia, Spain, Italy and Turkey. Venn (2009) argues that smallfirm exemptions are not a major source of inaccuracy in the overall OECD index,

\footnotetext{
${ }^{5}$ In fact, much of recent research on the effects of employment protection exploits the possibilities for identification provided by differential enforcement across types of firms. This literature is discussed in Section 3.3.
} 
although in some countries a large proportion of workers are affected by the exemptions.

Is the regulatory framework different for different groups in the labour market? It seems to be relatively common to differentiate between blue- and whitecollar workers and to impose stronger employment protection for the latter group (OECD, 1999). In many countries, apprentices, participants in training or labour market programmes and disabled workers are exempt from legislation (although antidiscrimination laws still apply). According to Venn (2009), few workers are affected by these targeted exemptions, typically less than 2 per cent of the labour force.

In most countries, the period of notice and severance pay (if applicable) increase with job tenure. In practice, this means that young people, who tend to have shorter tenure than others, are less protected than other groups. Seniority rules are also likely to have a differential impact depending on age and should contribute to increase the probability of dismissal for young workers. Since some groups are overrepresented among those with temporary employment, it is clear that regulations in this respect also have a differential impact across workers, even though the legislation may not be explicitly treating these groups differently. While a temporary job may be a stepping stone to permanent employment, there is also a risk for the creation of a dual labour market, with a core of permanent employees holding relatively secure jobs and a large group of workers circulating between temporary jobs and periods of unemployment. Workers with a temporary contract typically have less employment protection than permanent employees.

Figure 4 shows the unemployment rate among youth, relative to that of 25-54year-olds, during the period 1983-2009 for the same aggregate of countries as in Figures 1 and 2. No clear relationship between the strength of employment protection and the rate of unemployment among the youth as compared to older individuals in the various country groups can be discerned. There is a convergence in relative unemployment, from which only the Nordic countries diverge. In 2009, unemployment among the youth was around 2.5 times higher than unemployment in the older labour force in Continental Europe, Southern Europe and Anglo-Saxon countries and more than three times higher in the Nordic countries. It is noticeable that the European reforms concerning temporary employment during this period are not reflected in lower relative youth unemployment, with the possible exception of Southern Europe. 


\subsection{Implementation and enforcement}

The legislative complexity regarding employment protection makes it difficult to capture the stringency of legislation in available indices. In addition, differences in the implementation and enforcement of the law make it harder to find a true picture of the situation. Judicial interpretations of certain legal regulations - for example, what constitutes a just cause for dismissal - are not easy to quantify and the inclination to go to court with a dispute involving employment protection can vary across countries. The laws can also be optional, that is, they can be set aside by contract, in collective bargaining or otherwise. ${ }^{6}$

Some studies have investigated whether variations in macroeconomic conditions, above all the state of the business cycle, influence the implementation of legislation regarding employment protection (see, for example, Marinescu, 2011). The manner in which an economic downturn could influence the attitude of judges is not necessarily clear. On the one hand, the negative consequences of a firing are probably more pronounced for an employee in times of recession. On the other hand, the firm may also find itself in a precarious situation and at the risk of shutting down.

Another important aspect regarding the implementation of the law concerns collective bargaining and optional regulations. Sweden belongs to those countries in which the possibilities that a collective agreement can diverge from the legal regulations are especially far-reaching (Rönnmar, 2006). Departures from legislation in collective agreements can go either way in Sweden - in a more liberal or a more restrictive direction. In other countries, it appears to be the rule that collective agreements specify more restrictions in relation to the relevant legislation (OECD, 1999; Venn, 2009). In many collective agreements, for instance in the United States, seniority rules are stipulated (OECD, 1999; Kugler and Saint-Paul, 2004). If the coverage of the collective contract is low, which is the case in the United States, few people are affected by exceptions. Just as the decisions laid down by the courts appear to be influenced by the business cycle, so can the frequency and contents of those exceptions which can be considered optional be influenced by macroeconomic conditions. However, little is known as to how far this extends.

\footnotetext{
${ }^{6}$ Another potential problem is deficiencies in the legal system, making assumptions regarding the rule of law questionable. This kind of problem is often pervasive in developing countries and will not be further discussed here.
} 
Table 2, taken from Heyman and Skedinger (2011), illustrates a case of differential implementation of Swedish employment protection legislation in a selection of industries with different collective agreements. In 1997, a reform in the Employment Protection Act (EPA) stipulated that the length of notice in case of employer-initiated separations be based on tenure instead of age. This reform was implemented immediately, as it gained legal force, for blue-collar workers in the Engineering Agreement, but with a lag of up to four years in other agreements (white collar-workers in engineering, blue- and white-collar workers in construction and retail). During the period preceding implementation, the lagging agreements either observed notice regulations of their own or those prevailing in the pre-reform EPA (blue-collar workers in retail). Clearly, an analysis of the employment effects of the reform based on the naïve assumption of homogeneous, across-the-board implementation is likely to yield misleading results.

The perhaps most important omission in the OECD index is information on the actual enforcement of the legislation, a deficiency that the index shares with all other available alternatives. The OECD has the ambition to incorporate some aspects of both judicial decisions and optional rules via collective agreements when compiling their index, but information of this kind is decidedly lacking.

\subsection{Involuntary temporary employment}

The one-sided reform strategies in many European countries regarding regulation for regular and temporary work may have affected the labour market in several ways (which will be discussed in more detail in Section 3). One aspect, with potentially important welfare implications, is the extent to which workers regard their temporary positions as involuntary. Students working part-time or new entrants in the labour market trying out different jobs before deciding on a career may not be very interested in a permanent position. Workers beyond the initial phase of their labour market careers typically prefer a regular contract, though, as this increases job security and may also be a requirement for access to various services, such as renting a flat or borrowing from financial institutions.

The regressions in Table 3 represent an attempt to gauge the importance of employment protection legislation for involuntary temporary employment. The table displays cross-country regressions on an unbalanced panel of 20 European countries over the period 1985-2009. The dependent variables are based on survey data, 
collected by Eurostat, on the share of temporary workers in three different age groups $\left(15+, 15-24\right.$ and 25-49) who consider their temporary job as being involuntary. ${ }^{7}$

Since the dependent variables are relative (involuntary temporary employment as a percentage of total temporary employment), the extent of temporary employment as a whole is taken as given in the regressions. This should mitigate problems with reverse causality, in relation to the alternative with an absolute measure of involuntary temporary employment. The latter measure is related to the number of workers on fixed-term contracts, which may well influence the stringency of employment protection regulations. The regressions in the upper panel include as explanatory variables the unemployment rate (UNEMP), the OECD's indices for regulation of regular work (EP_R) and temporary work $\left(\mathrm{EP}_{-} \mathrm{T}\right)$ and a trend. The first three columns are based on the full sample. Unemployment contributes significantly to relatively more of involuntary temporary employment in all regressions. This is hardly surprising, since higher unemployment is likely to weaken the bargaining position of workers. Increased stringency in the employment protection indices seems in both cases to be associated with a larger share of involuntary temporary work. ${ }^{8}$ Young people seem to be particularly sensitive to regulation of permanent jobs; the coefficient for EP_R is substantially larger than the one for EP_T. An increase in the former index by 1 unit increases the share of involuntary temporary employment by 9.75 percentage points, while the corresponding figure for the latter index is 3.28. Stringent protection of regular work could make it more difficult to immediately find regular work and to transit from a temporary contract to a permanent one. Why stringent regulation of temporary work should be associated with a higher incidence of involuntary temporary jobs seems less straightforward.

Columns 4-6 in the upper panel report regressions for a subsample of observations with stricter than average regulation of regular work and more stringent regulation of regular jobs than temporary ones, in relation to the regulation in other countries (EP_R > 2 and EP_R > EP_T). For this subset of observations, there is an even larger tendency for EP_R to dominate over EP_T in influencing the dependent

\footnotetext{
${ }^{7}$ The dependent variables relate to those who have stated the response "Could not find permanent job" as the main reason for their temporary job. The other response alternatives are "Did not want a permanent job", "Education and training" and "Probationary period".

${ }^{8}$ The correlation between EP_R and EP_T in the data is modest $(0.21)$ and should present no problem in the estimations.
} 
variables, especially among those aged 15-24, while the estimates for UNEMP are not much different.

Regressions for the full sample with various fixed effects are presented in Columns 7-15. Time fixed effects (year dummies) do not change the results to any considerable extent as shown in Columns 7-9. Regressions with country fixed effects, implemented through "within" estimation, are reported in Columns 10-12. Countryspecific factors, like apprenticeship systems with temporary positions in which education and training are important, are likely to influence the degree to which workers report that their temporary work is involuntary (rather than stating "Education and training" as the main reason). The estimates for UNEMP remain positive and significant, as does the estimate for EP_R overall and among the young, but the magnitudes are reduced. The coefficients for EP_T are rendered insignificant. The fixed-effects regressions confirm the impression that EP_R is more important than EP_T for involuntary temporary employment, especially as far as youth are concerned, but it should be noted that there is relatively little variation in both EP_R and EP_T, and especially in EP_R, within countries. Both time and country fixed effects are included in the final three columns in the upper panel of Table 3. The coefficients of EP_R and EP_T are insignificant, but this is not the case for UNEMP (except in the regression for 25-49-year-olds).

The lower panel of Table 3 repeats the basic format of the upper panel, with the relative difference in stringency of regulations, EP_GAP, defined as (EP_REP_T)/EP_T, included instead of EP_R and EP_T. ${ }^{9}$ The gap variable comes out negatively in most regressions, but is positive and borderline significant for young people in the subsample with "high" protection of regular work and a more stringent regulation of regular jobs than temporary ones. With various fixed effects, most estimates of EP_GAP, with the exception of those for the 25-49 age group, are insignificant.

As checks for robustness, experiments with a different time period (19952009) and excluding countries in the sample with extensive apprenticeship systems

\footnotetext{
${ }^{9}$ This measure is used in OECD (2004) and corresponds to the theoretical concept in Blanchard and Landier (2002).
} 
(Austria, Denmark, Germany and the Netherlands) were performed. These checks yielded basically the same results as in the upper panel of Table $3 .^{10}$

My results indicate that it is mainly stringent regulation of permanent work that is associated with involuntary temporary work. Taken at face value, the findings suggest that the route taken by countries implementing one-sided reforms may well have entailed substantial costs in terms of lower welfare among temporary workers and that these costs are primarily borne by the young. A few caveats are warranted before drawing firm conclusions. First, the small degree of within-country variation in one of the variables of interest, regulation of permanent work, is cause for some concern. Moreover, even if a temporary job is subjectively regarded as involuntary, it could serve as a stepping stone to a permanent contract and thus enhance the individual's welfare in the future. If the alternative to a temporary job is unemployment, rather than regular work, temporary jobs should be welfareimproving. It is possible that the results do not only reflect that stringent regulation of regular work reduces access to such jobs, but also that regular employment becomes more attractive in relation to temporary work, making those in the latter type of employment more inclined to label it as "involuntary" or more eager to search for permanent jobs. Another concern with the estimates is the remaining potential for reverse causality, despite the choice of the share of involuntary temporary employment as the dependent variable. If, for example, the dissatisfaction with temporary work is increasing, this could influence the employment protection legislation. A policy response could be to change regulations for temporary work, possibly in a more stringent direction, while it seems less obvious that protection of regular employment would be reformed (for which the strongest results are obtained). Hence, I find it improbable that reverse causality distorts the main conclusions in the analysis, but it cannot be ruled out that the estimates are affected to some degree.

\footnotetext{
${ }^{10}$ With the shorter estimation period, EP_R turned out to be insignificant in some of the regressions for the age groups $15+$ and $25-49$.
} 


\section{Empirical studies on the employment effects of employment protection legislation}

The presentation in this section is organized according to the manner in which the studies were set up: Cross-country analyses with aggregate data, cross-country-studies with disaggregate data and within-country studies. The review comprises the period from 1990 to the present.

\subsection{Cross-country studies: aggregate data}

In these studies, cross-country variation in the stringency of employment protection is the main basis for identification of the effects. The development within the field has gone from pure cross-country analysis towards an increased use of panel data where variation over time is also considered.

One of the pioneering studies of the impact of employment protection on aggregate employment and unemployment is Lazear (1990). He uses data concerning notification time and severance pay for 22 different countries in the period 19561984. According to the results, employment is lower and unemployment (including long-term unemployment) is higher in countries with more stringent employment protection. The measure of the strictness of legislation is relatively narrow. In a later study, Lazear's (1990) study has been expanded in several respects by Addison and Teixeira (2005). Among other things, they add more years and explanatory variables to the analysis, a more comprehensive measure of employment protection is used and various robustness tests are carried out. The authors conclude that unemployment increases in most of the estimates, but the results concerning employment and longterm unemployment are much weaker than in Lazear's study.

In addition to constructing indices on a regular basis regarding employment protection, the OECD has also produced a number of influential studies regarding its effects. Their conclusions have been modified over time. Scarpetta (1996) and Elmeskov et al. (1998) analyse the effects on structural unemployment. ${ }^{11}$ They find that unemployment increases with more stringent employment protection (the results are more robust in the latter study). The OECD (1999) uncovers no relation, however, between employment protection and the level of unemployment and no strong

\footnotetext{
${ }^{11}$ Structural unemployment is based on estimations of the unemployment rate at which wage growth does not increase (NAWRU).
} 
connection for employment, but the flows into and out of unemployment decrease, while the duration of unemployment increases. ${ }^{12}$ Similarly, Bassanini and Duval (2006) find no evidence that the stringency of legislation has any effect on aggregate unemployment. In the later OECD studies, the time periods considered are longer, the number of countries is greater and the index regarding employment protection is more comprehensive and with more observations over time in panel analyses (in the most recent one, yearly variation in the index is used). In addition, more robustness tests have been carried out.

The mixed results in the OECD studies concerning the effects on aggregate employment and unemployment are representative for the state of research in general among those studies which are based on cross-country aggregate data. On the one hand, there are a number of studies suggesting that employment falls or unemployment rises. See, for example, Blanchard and Wolfers (2000), Botero et al. (2004), Di Tella and McCulloch (2005), Heckman and Pagés-Serra (2000) and Nickell (1997). On the other hand, there are studies indicating no effect at all, or that employment increases or unemployment falls. See, for example, Allard and Lindert (2007), Baccaro and Rei (2007), Belot and van Ours (2004) and Garibaldi and Violante (2005).

As far as unemployment and employment in various demographic groups is concerned, however, there are more results which indicate adverse effects on young people (and in many cases women). Allard and Lindert (2007), Bertola et al. (2007), Botero et al. (2004), Heckman and Pagés-Serra (2000), OECD (2004) and Skedinger (1995) all find that more stringent employment protection diminishes employment or increases unemployment among these groups. However, there are examples of divergent studies where the effects on employment possibilities for youth are nonexistent (OECD, 1999).

One hypothesis in the literature is that the effects of employment protection are stronger if wages cannot be adjusted downwards in order to compensate for the increased costs due to the legislation. If insiders have a strong bargaining position in the labour market, this can reduce the possibilities for employers to shift the costs to the employees. It is frequently assumed that wage demands from insiders have less impact in either decentralized or centralized bargaining systems than in systems where

\footnotetext{
${ }^{12}$ OECD (2004) finds similar results.
} 
wages are mainly negotiated at the industry level and where co-ordination is limited (Calmfors and Driffill, 1988).

This hypothesis gains some support in Elmeskov et al. (1998), who find that a more stringent legislation contributes to higher unemployment only at the intermediate level of bargaining. The results in the OECD study from 1999 show that stronger employment protection reduces unemployment if the centralization and coordination levels are high (that is to say, the relationship is linear and not humpshaped). The results of Bassanini and Duval (2006) suggest a hump-shape, but their findings are not robust. Belot and van Ours (2004), whose results indicate that employment protection has a negative effect on unemployment, also report results which suggest that this effect only comes into play when wage formation is decentralized.

A few studies have examined interactions between employment protection and macroeconomic shocks, in which the hypothesis is that a more stringent legislation (and rigidity in other labour market institutions) has stronger negative effects on employment when the economy is subject to disturbances. This may explain why the stable differences in the levels of employment protection over time and across countries did not have any influence on differences in unemployment during the 1950s and the 1960s, but may have had an influence thereafter. This hypothesis finds support in Blanchard and Wolfers (2000), who consider shocks in the form of changes in productivity and real interest rates as well as shifts in labour demand.

In a later study by Nickell et al. (2005), there are in most cases no significant interaction effects (they also control for shocks in monetary supply and import prices). Similarly, Bassanini and Duval (2006) find ambiguous results. Stringent legislation seems to dampen the unemployment-increasing effect in the short term in case of macroeconomic shocks, but prolongs the period required for unemployment to return to its previous level. Evaluating the effects of employment protection legislation on structural unemployment in economic downturns, Furceri and Mourougane (2009) find that crises increase structural unemployment in countries with above average stringency in employment protection.

The results in the various studies based on aggregate data point in different directions. It seems difficult to substantiate that there is a robust relationship between employment protection and aggregate employment or unemployment. The clearest findings appear to be that the flows into and out of employment and unemployment 
diminish, and that youth are adversely affected. Studies regarding other vulnerable groups, such as immigrants, appear to be scarce. There are also many results which suggest that interactions with other labour market institutions and macroeconomic shocks play a role, but the estimates are not very robust. In general, the studies continue to be plagued by little variation in employment protection within countries as well as potential problems with reverse causality, that is, the possibility that the labour market situation affects the stringency of legislation.

Cross-country studies using aggregate data thus have weaknesses, but one of their advantages is that they make it possible to consider general equilibrium effects. Studies with disaggregate data do not easily give information on aggregate effects.

\subsection{Cross-country studies: disaggregate data}

The majority of studies within this still relatively unexplored area of the literature analyse effects of employment protection on job reallocation and firm dynamics. Only a few studies research effects on the level of employment.

Some studies examine job reallocation and its components, that is to say, the creation and destruction of jobs. ${ }^{13}$ Job reallocation is substantial in all countries, but there are significant differences across industries (Haltiwanger et al., 2006). In this research area, the difficulties in finding comparable data have been considerable. ${ }^{14}$ In some of the earlier studies, it has been observed that the aggregate reallocation of jobs is approximately equally as large in countries with differing levels of employment protection, which contradicts one of the few unambiguous predictions of the theory (see, for example, Bertola and Rogerson, 1997).

In later studies, in which more comparable data are available, it appears, however that the results are more aligned to theoretical predictions. Negative effects on job reallocation are found in Gómez-Salvador et al. (2004), Haltiwanger et al. (2006), Messina and Vallanti (2007), Micco and Pagés (2006) and Salvanes (1997). Furthermore, Messina and Vallanti (2007) find that stronger employment protection

\footnotetext{
${ }^{13}$ Many studies follow the convention of Davis and Haltiwanger (1999), where job creation in any given industry is calculated as the weighted sum of employment increases in firms which have increased the number of employees and job destruction is calculated as the weighted sum of the absolute employment reductions in firms which have decreased the number of employees in the same industry. Job reallocation is the sum of job creation and job destruction.

${ }^{14}$ The difficulties in comparing across countries are related to (among other things) differences in (1) units of observation (firms or establishments); (2) size thresholds for inclusion in the data; and (3) coverage of various industries.
} 
contributes to making job reallocation more pro-cyclical; that is to say, it increases more in upturns and decreases more in downturns. According to the authors, this means that employment protection above all reduces the sensitivity of job destruction to the various stages in the business cycle.

Boeri and Garibaldi (2009) uncover a positive relationship between mobility and the lower stringency of employment protection that characterizes many European countries since 1985. Mobility is measured in several ways, as unemployment inflows and outflows, mobility across labour market states and as job-to-job flows.

Only a few studies consider the effects on the level of employment and its composition. Micco and Pagés (2006) find that employment decreases with more stringent employment protection and that this effect is mainly due to fewer new firms, whereas employment in existing companies is not affected. The effects of employment protection on the employment of immigrants have been investigated by Causa and Jean (2007) and Sá (2008). Both studies differentiate between regulation for permanent and temporary contracts. Causa and Jean (2007) find that a larger difference in stringency between the two increases employment among immigrants. The results in Sá (2008) indicate that, among natives, stronger regulation for permanent contracts decreases employment and regulation for temporary contracts increases employment, while immigrants are much less affected in general. She argues that immigrants are less aware of employment protection legislation than natives and therefore less likely to claim their rights.

More stringent employment protection can lead to employers being more selective in their recruiting of new employees. Daniel and Siebert (2005) demonstrate that the educational level of new employees rises in countries with stronger protection.

Kahn (2007) analyses the effects of employment protection on employment and the incidence of temporary employment in various demographic groups. According to his results, more stringent regulation reduces employment among youth and immigrants relative to other groups. If employed, it is more likely that women and immigrants have temporary jobs. With a high coverage of collective bargaining, these tendencies are reinforced, which suggests that high wage floors make a downward adjustment of wages more difficult. In a related study, Kahn (2010) investigates the effects of reforms of regulations for temporary and permanent contracts in Europe since the 
mid-1990s. He concludes that liberalization of rules - for either type of contract - had no effect on total employment. The incidence of temporary jobs increased when it became easier to use temporary contracts, though, which suggests that employers mainly substituted temporary workers for permanent ones.

\section{3. Within-country studies}

Employment protection legislation tends to be changed only slowly and in small steps. Therefore, many of the reforms have been too marginal for discovering any noticeable effects. Another problem with most of the reforms from the perspective of an evaluation is that they have been designed in such a way that everyone in the labour market is affected by the reforms, which means that there are few or no suitable control groups. In a number of reforms in various countries - for example, Portugal in 1989, Italy in 1990, Germany in 1996, 1999 and 2004, and Sweden in 2001 - small companies have nevertheless been given special treatment vis-à-vis large ones. In all these cases, the legislation either became more stringent or less restrictive for small firms, while regulations for large firms in most cases remained unchanged.

In Spain, a reform was put through in 1997, whereby firing costs for permanent employees were reduced only for certain demographic groups. Such partial reforms create suitable control groups, which can be assumed to be unaffected by the reforms. This makes it easier to identify the effects.

In other countries, such as the United States and Canada, regional differences in legislation have also been exploited in the research. In the United States, employers have traditionally been able to fire employees at any point in time and for any reason, according to the "employment-at-will" principle. Over the course of time since the 1970s, most of the states have introduced various exemptions from this principle, but at different times and covering different areas of the legislation. This has resulted in regional differences in legislation.

Another advantage in studies of single countries is that the possibilities to control for country-specific conditions are greater than in those which are based on cross-country data. One disadvantage, though, is that the possibility to make generalizations which carry over to other countries can be limited due to these country-specific factors. 
The analyses use disaggregate data in general - on the individual, firm or regional level. Like cross-country studies, the country-specific studies also tend to find evidence that increased stringency in employment protection legislation reduces labour market dynamics. Kugler and Pica $(2006,2008)$ exploit the reform in Italy in 1990, which made small firms with less than 15 employees, which had earlier been totally exempt from the regulations, pay higher firing costs than previously (though still at a lower level than larger companies). According to their results, both inflow and outflow of employment in the small firms, relative to the flows in larger firms, were reduced. Similarly, Cingano et al. (2008) find that job reallocation decreased in small firms after the 1990 reform in Italy.

Autor et al. (2007) show that job reallocation is lower in those parts of the United States which have implemented more stringent exceptions to the principle of employment at will. The analysis in Martins (2009) is an exception, where no effect on job reallocation is established. He studies a reform in Portugal in 1989, which allowed small firms with no more than 20 employees to fall under more liberal legislation regarding dismissals for personal reasons. A reform of seniority rules in Sweden in 2001

is analysed by von Below and Skogman Thoursie (2010). The reform made it possible for firms with a maximum of ten employees to exempt two persons from the seniority list when firing due to lack of work. The authors find that hirings and firings increased in small firms after the reform, but unveil no effect on net employment in general except an increase, albeit a small one, for immigrants.

A number of studies have analysed the reforms of employment protection undertaken in Germany and their effects on employment flows. Bauer et al. (2007) do not find any effect on employment flows in their study, which exploits the reforms in 1996 and 1999. Boockmann et al. (2008), however, find clear evidence that the 1999 reform, which implied stronger employment protection in small firms, contributed to increasing job stability. They take into account the six-month waiting period before the legislation takes effect (for the individual worker) and argue that previous results for Germany that omit to do this are misleading. The 2004 reform of employment protection is examined by Bauernschuster (2009). He finds that the relaxation of dismissal protection in small firms led to a small positive effect on hirings and no effect on separations. Above all, the reform caused considerable substitution by type 
of employment contract. That is, firms became prone to hire workers on permanent rather than temporary contracts, in relation to the situation before the reform.

Some studies investigate the probability of involuntary separation as a consequence of higher firing costs. Givord and Maurin (2004) study how the probability of involuntary separation is influenced by reforms in legislation regarding employment protection in France. They find that this probability decreases during the more stringent regimes. Boeri and Jimeno (2005) obtain results which indicate that involuntary separation is less common in companies with more stringent employment protection in Italy and Spain. Marinescu (2009) examines a reform in Great Britain in 1999, where the tenure necessary to qualify for protection against unfair dismissal was decreased from two years to one. The probability of being fired decreased for workers with 1-2 years of tenure, relative to workers with longer tenure, mainly due to employers being more selective in their recruitment.

An important question is how employment protection influences the possibility for someone who is unemployed to find a new job compared to other groups. One hypothesis in the literature is that employers to a much higher degree are inclined to hire an employee who is already employed before someone who is unemployed if the legislation is stringent, since it is potentially more expensive to hire a "wild card". Kugler and Saint-Paul (2004) find results for the United States which indicate that unemployed individuals are disadvantaged in this respect in states with stronger employment protection. A potential negative signalling effect of becoming unemployed may, however, be mitigated by seniority rules, where tenure is the sole criterion for being fired. Kugler and Saint-Paul (2004) also find support for the idea that negative effects on job prospects are weaker among employees who belong to a union, for whom seniority rules often apply in the United States.

A number of studies research the effects on the level of employment. Here the results are somewhat mixed: Kugler et al. (2002), Martins (2009), Sá (2008) and Schivardi and Torrini (2008) find that employment decreases under more stringent legislation; Bird and Knopf (2009) and Miles (2000) find no effect, while Autor et al. (2007) estimate positive effects. The conflicting results in these studies may be due to employment effects being different for different groups. ${ }^{15}$ MacLeod and Nakavachara (2007), who study the effects of exceptions to the principle of employment at will in

\footnotetext{
${ }^{15}$ The different results in some of the American studies seem to depend upon differences in estimation methods and classifications of laws (see Autor et al., 2004).
} 
the United States, find that employment increases in jobs which require higher education and in rural areas, where mobility costs are higher than in the cities. Among those with lower levels of education, however, employment is reduced with stricter regulations. The results in Kugler and Pica (2006) indicate that employment for males increases, while it decreases for females.

Many studies explore the effects of reforms regarding temporary employment, which has been the most common kind of reform of employment protection in Europe. One of the risks of having many employees with temporary contracts is that the labour force becomes more segmented. Another risk is that unemployment to a lesser degree serves as a check on wage increases for permanent employees. Limiting the possibilities of temporary employment may lead to other problems, though, such as fewer jobs being offered to the unemployed. Bentolila and Dolado (1994) find that liberalization of regulations regarding temporary employment leads to increased wages for permanent employees in Spain, where regulations for permanent employment have been particularly strict. ${ }^{16}$ Boeri and Garibaldi (2007) study employment effects after a regulatory reform of temporary contracts in Italy. According to their results, employment increased following the relaxation of regulation, but only temporarily. Autor (2003) finds that the increase in employment in the temporary work agency sector in the United States can largely be explained by stronger employment protection implemented by some states.

Studies of single countries give additional support for the idea that employment protection decreases flows in the labour market. In many of the studies for single countries, partial reforms have been exploited, which allows for a more reliable identification of employment effects than in other studies. However, there is no clear indication that the exploitation of partial reforms or the use of micro data has affected results regarding employment and unemployment in any systematic way. ${ }^{17}$

The number of reforms analysed is relatively small and many studies use the same reform. In addition, general equilibrium effects are ignored, that is to say, the influence on other groups than the group under study. Furthermore, non-random selection within this group can be a problem.

\footnotetext{
${ }^{16}$ They find similar results for a number of other European countries.

${ }^{17}$ This conclusion is based on experiments with ordered probit regressions on around 90 regression results on employment, employment and labour force participation reported in the 15-page appendix in Skedinger (2010).
} 


\section{Conclusions}

The empirical research reviewed in this article suggests that employment protection legislation contributes to less turnover and job reallocation. It cannot be demonstrated that aggregate employment and unemployment over the business cycle are affected to any considerable extent, but the labour market prospects of youth and other marginal groups seem to worsen as a consequence of increased stringency of the legislation. It is debatable whether marginal groups have gained much from the widespread policy strategy to liberalize regulations of temporary employment and leave regulations of regular employment intact. This policy has created incentives for employers to substitute temporary workers for permanent ones. Stronger protection of regular jobs appears to be associated with more involuntary temporary employment, particularly among the young. Research methods and data availability have improved in many ways during the period covered. More reliable identification of effects through the exploitation of partial reforms or the use of micro data do not, however, appear to have affected the results regarding employment and unemployment in any systematic way. One important shortcoming with the micro studies, though, is that they ignore general equilibrium effects.

Some of the effects of employment protection legislation are clearly intended by the legislators, such as the reduced risk of being fired. Other effects are probably not specifically desired, but may be tolerated. The weakening of the position of vulnerable groups in the labour market can be seen as one of these. The more difficult question is the extent of weakening that can be regarded as acceptable. Youth tend to have a lower opportunity cost than older people of being non-employed, since, for example, continued education in general is a relatively more attractive alternative to employment. This argument carries less weight, however, for other vulnerable groups, such as immigrants and the work disabled. For these groups, unemployment is, to a much higher degree, the alternative to employment.

To what extent has employment protection legislation contributed to employment stability during the recent worldwide recession? Firm conclusions in this matter cannot yet be reached, but previous research points to some factors of importance. While jobs will typically be protected in the initial phase of a downturn, a decrease in job reallocation may be detrimental to employment growth in later phases. 
The magnitude of the recent crisis surpasses those experienced in most industrialized countries during the postwar period by a wide margin, so that high costs of dismissing workers may have had less of a preventive effect than previously. Another difference to past downturns is that in many countries, relatively more workers are on temporary contracts, for which there is little protection. In countries that have one-sidedly softened regulations for temporary contracts, permanent-contract workers who have lost their jobs may have to return to temporary employment to an increasing extent, which could contribute to higher unemployment (Boeri and Garibaldi, 2009). The risks for such a scenario, or that employers choose not to hire at all in response to stringent employment protection legislation, are likely to increase with widespread uncertainty about the economic recovery (Lindbeck, 1993).

There are still gaps and unresolved points in the literature which make it difficult to expound with any certainty on the aggregate welfare effects of employment protection. This is also a drawback on attempts to sketch thorough changes in the design of employment protection based on the knowledge provided by research, despite the identification of a number of positive and negative effects of employment protection. For example, research seems to have relatively little to say about (1) how strict optimal regulations should be; and (2) according to which dimensions (seniority rules, notice periods, severance pay, etc.) the regulatory framework should be redesigned. However, a great deal of research points to risks of labour market segmentation with a large difference in stringency between regulations for permanent and temporary contracts.

Another important aspect which should be taken into account in any discussion of these results is the enforcement of employment protection legislation. For example, the implications of optional employment protection legislation have hardly been researched, neither theoretically nor empirically.

Policy proposals will also have to consider that employment protection systems do not operate in isolation, but interact with other labour market, product market and social institutions. Much of the empirical research in this field is inconclusive, partly because there is relatively little variation in the particular combinations of these institutions across countries. The existence of institutional interactions also implies that caution is warranted when considering "importing" specific employment protection designs from other countries. 
Table 1. Stringency of employment protection legislation in OECD countries, 2008. Index

\begin{tabular}{|c|c|c|c|c|}
\hline Country & $\begin{array}{c}\text { Summary } \\
\text { index }\end{array}$ & $\begin{array}{c}\text { Regular } \\
\text { employment } \\
\text { (weight 5/12) }\end{array}$ & $\begin{array}{l}\text { Temporary } \\
\text { employment } \\
\text { (weight 5/12) }\end{array}$ & $\begin{array}{l}\text { Collective } \\
\text { dismissals } \\
\text { (weight 2/12) }\end{array}$ \\
\hline Australia & 1.4 & 1.4 & 0.8 & 2.9 \\
\hline Austria & 2.4 & 2.2 & 2.3 & 3.3 \\
\hline Belgium & 2.6 & 1.9 & 2.7 & 4.1 \\
\hline Canada & 1.0 & 1.2 & 0.2 & 2.6 \\
\hline Czech Republic & 2.3 & 3.0 & 1.7 & 2.1 \\
\hline Denmark & 1.9 & 1.5 & 1.8 & 3.1 \\
\hline Finland & 2.3 & 2.4 & 2.2 & 2.4 \\
\hline France $^{\mathrm{a}}$ & 2.9 & 2.6 & 3.5 & 2.1 \\
\hline Germany & 2.6 & 2.9 & 2.0 & 3.8 \\
\hline Greece & 3.0 & 2.3 & 3.5 & 3.3 \\
\hline Hungary & 2.1 & 1.8 & 2.1 & 2.9 \\
\hline Iceland & 2.1 & 2.1 & 1.5 & 3.5 \\
\hline Ireland & 1.4 & 1.7 & 0.7 & 2.4 \\
\hline Italy & 2.6 & 1.7 & 2.5 & 4.9 \\
\hline Japan & 1.7 & 2.1 & 1.5 & 1.5 \\
\hline Korea & 2.1 & 2.3 & 2.1 & 1.9 \\
\hline Luxembourg & 3.4 & 2.7 & 3.9 & 3.9 \\
\hline Mexico & 3.2 & 2.3 & 4.0 & 3.8 \\
\hline Netherlands & 2.2 & 2.7 & 1.4 & 3.0 \\
\hline New Zealand & 1.2 & 1.5 & 1.1 & 0.4 \\
\hline Norway & 2.7 & 2.2 & 3.0 & 2.9 \\
\hline Poland & 2.4 & 2.0 & 2.3 & 3.6 \\
\hline Portugal $^{\mathrm{a}}$ & 2.8 & 3.5 & 2.5 & 1.9 \\
\hline Slovakia & 2.1 & 2.5 & 1.2 & 3.8 \\
\hline Spain & 3.1 & 2.4 & 3.8 & 3.1 \\
\hline Sweden & 2.1 & 2.7 & 0.7 & 3.8 \\
\hline Switzerland & 1.8 & 1.2 & 1.5 & 3.9 \\
\hline Turkey & 3.5 & 2.5 & 4.9 & 2.4 \\
\hline United Kingdom & 1.1 & 1.2 & 0.3 & 2.9 \\
\hline United States & 0.9 & 0.6 & 0.3 & 2.9 \\
\hline OECD average & 2.2 & 2.1 & 2.1 & 3.0 \\
\hline
\end{tabular}

Note: ${ }^{\text {a }} 2009$. The scale of the index is $0-6$, where 6 represents the most stringent legislation. Unlike earlier versions, the OECD index (version 3) incorporates three additional components of legislation: "the maximum time allowed for an employee to make a claim of unfair dismissal"; "administrative authorization and regular reporting requirements for temporary work agencies"; and "the requirement for temporary work agency workers to receive the same pay and conditions as regular workers at the user firm".

Source: OECD. 
Table 2. Reforms of terms of notice for employer-initiated separations in selected collective agreements in Sweden, 1997-2001

\begin{tabular}{|l|l|l|l|l|l|l|}
\hline \multirow{2}{*}{ Industry } & \multicolumn{3}{|c|}{ Manual Workers } & \multicolumn{3}{c|}{ Non-manual workers } \\
\cline { 2 - 7 } & $\begin{array}{l}\text { Pre-reform } \\
\text { rules }\end{array}$ & $\begin{array}{l}\text { Post-reform } \\
\text { rules }\end{array}$ & $\begin{array}{l}\text { Date of } \\
\text { reform }\end{array}$ & $\begin{array}{l}\text { Pre-reform } \\
\text { rules }\end{array}$ & $\begin{array}{l}\text { Post-reform } \\
\text { rules }\end{array}$ & $\begin{array}{l}\text { Date of } \\
\text { reform }\end{array}$ \\
\hline Engineering & $\begin{array}{l}\text { Old EPA, } \\
\text { age-based }\end{array}$ & $\begin{array}{l}\text { New EPA, } \\
\text { tenure-based }\end{array}$ & 1997 & $\begin{array}{l}\text { CA-NM, } \\
\text { age/tenure- } \\
\text { based }\end{array}$ & $\begin{array}{l}\text { New EPA, } \\
\text { tenure-based }\end{array}$ & 2001 \\
\hline Construction & $\begin{array}{l}\text { CA-C, } \\
\text { age-based }\end{array}$ & $\begin{array}{l}\text { New EPA, } \\
\text { tenure-based }\end{array}$ & $2000-01$ & $\begin{array}{l}\text { CA-NM, } \\
\text { age/tenure- } \\
\text { based }\end{array}$ & $\begin{array}{l}\text { New EPA, } \\
\text { tenure-based }\end{array}$ & 1998 \\
\hline Retail & $\begin{array}{l}\text { Old EPA, } \\
\text { age-based }\end{array}$ & $\begin{array}{l}\text { New EPA, } \\
\text { tenure-based }\end{array}$ & 2001 & Various & Various & Various \\
\hline
\end{tabular}

Note: Old (New) EPA= rules in accordance with the Employment Protection Act up to 1997 (after 1997); CA = rules specific to collective agreement for manual workers in construction (C) or for nonmanual workers (NM) in general. Implementation for non-manual workers in retail varies depending on the specific agreement.

Source: Heyman and Skedinger (2011). 
Table 3. Regressions for involuntary temporary employment, various age groups, 1985-2009

\begin{tabular}{|c|c|c|c|c|c|c|c|c|c|c|c|c|c|c|c|}
\hline \multirow[t]{2}{*}{ Variable } & \multicolumn{3}{|c|}{ Full sample } & \multicolumn{3}{|c|}{$\begin{array}{c}\text { Sample with } \\
\text { EP_R }>2 \& \text { EP_R }>E_{-} \text {T }\end{array}$} & \multicolumn{3}{|c|}{$\begin{array}{c}\text { Full sample } \\
\text { Time fixed effects }\end{array}$} & \multicolumn{3}{|c|}{$\begin{array}{c}\text { Full sample } \\
\text { Country fixed effects }\end{array}$} & \multicolumn{3}{|c|}{$\begin{array}{c}\text { Full sample } \\
\text { Both time and country } \\
\text { fixed effects }\end{array}$} \\
\hline & $15+$ & $15-24$ & $25-49$ & $15+$ & $15-24$ & $25-49$ & $15+$ & $15-24$ & $25-49$ & $15+$ & $15-24$ & $25-49$ & $15+$ & $15-24$ & $25-49$ \\
\hline UNEMP & $\begin{array}{l}2.75 \\
(10.16)\end{array}$ & $\begin{array}{l}3.12 \\
(10.55)\end{array}$ & $\begin{array}{l}2.42 \\
(10.28)\end{array}$ & $\begin{array}{l}3.21 \\
(8.53)\end{array}$ & $\begin{array}{l}3.90 \\
(9.31)\end{array}$ & $\begin{array}{l}2.76 \\
(7.85)\end{array}$ & $\begin{array}{l}2.80 \\
(9.94)\end{array}$ & $\begin{array}{l}3.21 \\
(10.38)\end{array}$ & $\begin{array}{l}2.45 \\
(10.00)\end{array}$ & $\begin{array}{l}0.98 \\
(3.60)\end{array}$ & $\begin{array}{l}1.62 \\
(6.52)\end{array}$ & $\begin{array}{l}0.63 \\
(2.45)\end{array}$ & $\begin{array}{l}0.73 \\
(2.10)\end{array}$ & $\begin{array}{l}1.13 \\
(3.61)\end{array}$ & $\begin{array}{l}0.37 \\
(1.13)\end{array}$ \\
\hline EP_R & $\begin{array}{l}5.56 \\
(4.64)\end{array}$ & $\begin{array}{l}9.75 \\
(7.60)\end{array}$ & $\begin{array}{l}4.34 \\
(4.18)\end{array}$ & $\begin{array}{l}11.17 \\
(3.82)\end{array}$ & $\begin{array}{l}22.40 \\
(6.91)\end{array}$ & $\begin{array}{l}8.44 \\
(3.09)\end{array}$ & $\begin{array}{l}5.62 \\
(4.58)\end{array}$ & $\begin{array}{l}9.81 \\
(7.41)\end{array}$ & $\begin{array}{l}4.43 \\
(4.16)\end{array}$ & $\begin{array}{l}5.99 \\
(1.84)\end{array}$ & $\begin{array}{l}6.65 \\
(2.25)\end{array}$ & $\begin{array}{l}3.61 \\
(1.18)\end{array}$ & $\begin{array}{l}3.61 \\
(0.99)\end{array}$ & $\begin{array}{l}1.92 \\
(0.58)\end{array}$ & $\begin{array}{l}2.29 \\
(0.67)\end{array}$ \\
\hline $\mathrm{EP} \_\mathrm{T}$ & $\begin{array}{l}4.79 \\
(6.65)\end{array}$ & $\begin{array}{l}3.28 \\
(4.23)\end{array}$ & $\begin{array}{l}3.67 \\
(5.87)\end{array}$ & $\begin{array}{l}7.52 \\
(2.93)\end{array}$ & $\begin{array}{l}-2.13 \\
(0.75)\end{array}$ & $\begin{array}{l}4.32 \\
(1.80)\end{array}$ & $\begin{array}{l}4.55 \\
(6.08)\end{array}$ & $\begin{array}{l}3.21 \\
(3.96)\end{array}$ & $\begin{array}{l}3.40 \\
(5.24)\end{array}$ & $\begin{array}{l}-0.39 \\
(0.40)\end{array}$ & $\begin{array}{l}1.13 \\
(1.27)\end{array}$ & $\begin{array}{l}1.17 \\
(1.27)\end{array}$ & $\begin{array}{l}-2.18 \\
(1.62)\end{array}$ & $\begin{array}{l}-1.83 \\
(1.50)\end{array}$ & $\begin{array}{l}-0.26 \\
(0.20)\end{array}$ \\
\hline TREND & $\begin{array}{l}0.21 \\
(1.30)\end{array}$ & $\begin{array}{l}-0.03 \\
(0.19)\end{array}$ & $\begin{array}{l}0.18 \\
(1.28)\end{array}$ & $\begin{array}{l}-0.03 \\
(0.08)\end{array}$ & $\begin{array}{l}-0.48 \\
(1.31)\end{array}$ & $\begin{array}{l}-0.17 \\
(0.57)\end{array}$ & & & & & & & & & \\
\hline $\begin{array}{l}\text { Mean of } \\
\text { dep. var. }\end{array}$ & 58.32 & 48.65 & 68.61 & 58.02 & 50.06 & 68.64 & 58.32 & 48.65 & 68.61 & 58.32 & 48.65 & 68.61 & 58.32 & 48.65 & 68.61 \\
\hline R-sq (adj) & 0.354 & 0.385 & 0.335 & 0.472 & 0.496 & 0.389 & 0.329 & 0.356 & 0.313 & 0.199 & 0.381 & 0.274 & 0.077 & 0.150 & 0.173 \\
\hline Prob $>F$ & 0.000 & 0.000 & 0.000 & 0.000 & 0.000 & 0.000 & 0.000 & 0.000 & 0.000 & 0.001 & 0.000 & 0.017 & 0.169 & 0.000 & 0.242 \\
\hline No. obs & 332 & 324 & 331 & 137 & 137 & 137 & 332 & 324 & 331 & 332 & 324 & 331 & 332 & 324 & 331 \\
\hline
\end{tabular}


b)

\begin{tabular}{|c|c|c|c|c|c|c|c|c|c|c|c|c|c|c|c|}
\hline \multirow[t]{2}{*}{ Variable } & \multicolumn{3}{|c|}{ Full sample } & \multicolumn{3}{|c|}{$\begin{array}{c}\text { Sample with } \\
\text { EP_R }>2 \text { \& EP_R }>\text { EP_T }\end{array}$} & \multicolumn{3}{|c|}{$\begin{array}{c}\text { Full sample } \\
\text { Time fixed effects }\end{array}$} & \multicolumn{3}{|c|}{$\begin{array}{c}\text { Full sample } \\
\text { Country fixed effects }\end{array}$} & \multicolumn{3}{|c|}{$\begin{array}{c}\text { Full sample } \\
\text { Both time and country } \\
\text { fixed effects } \\
\end{array}$} \\
\hline & $15+$ & $15-24$ & $25-49$ & $15+$ & $15-24$ & $25-49$ & $15+$ & $15-24$ & $25-49$ & $15+$ & $15-24$ & $25-49$ & $15+$ & $15-24$ & $25-49$ \\
\hline UNEMP & $\begin{array}{l}2.97 \\
(9.95)\end{array}$ & $\begin{array}{l}3.13 \\
(9.20)\end{array}$ & $\begin{array}{l}2.59 \\
(10.08)\end{array}$ & $\begin{array}{l}2.57 \\
(6.06)\end{array}$ & $\begin{array}{l}.54 \\
(5.30)\end{array}$ & $\begin{array}{l}2.22 \\
(5.99)\end{array}$ & $\begin{array}{l}3.02 \\
(9.70)\end{array}$ & & $\begin{array}{l}2.60 \\
(9.74)\end{array}$ & $\begin{array}{l}1.15 \\
(3.94)\end{array}$ & $\begin{array}{l}1.86 \\
(6.95)\end{array}$ & $\begin{array}{l}1.00 \\
(3.69)\end{array}$ & $\begin{array}{l}1.01 \\
(2.75)\end{array}$ & $\begin{array}{l}1.41 \\
(4.28)\end{array}$ & $\begin{array}{l}0.73 \\
(2.17)\end{array}$ \\
\hline EP_GAP & & & $\begin{array}{l}-2.35 \\
(4.44)\end{array}$ & & $\begin{array}{l}2.42 \\
(1.81)\end{array}$ & & $\begin{array}{l}-3.08 \\
(4.85)\end{array}$ & & & & & & & & $\begin{array}{l}-1.91 \\
(232)\end{array}$ \\
\hline TREND & $\begin{array}{l}-0.06 \\
(0.37) \\
\end{array}$ & $\begin{array}{l}-0.22 \\
(1.17) \\
\end{array}$ & $\begin{array}{l}-0.03 \\
(0.20)\end{array}$ & $\begin{array}{l}-1.29 \\
(4.13)\end{array}$ & $\begin{array}{l}-1.75 \\
(4.97)\end{array}$ & $\begin{array}{l}-1.07 \\
(3.91)\end{array}$ & & & & & & & & & \\
\hline $\begin{array}{l}\text { Mean of } \\
\text { dep. var. }\end{array}$ & 58.32 & 48.65 & 68.61 & 58.02 & 50.06 & 68.64 & 58.32 & 48.65 & 68.61 & 58.32 & 48.65 & 68.61 & 58.32 & 48.65 & 68.61 \\
\hline R-sq (adj) & 0.250 & 0.219 & 0.247 & 0.284 & 0.289 & 0.271 & 0.227 & 0.180 & 0.227 & 0.255 & 0.222 & 0.181 & 0.246 & 0.215 & 0.191 \\
\hline Prob $>F$ & 0.000 & 0.000 & 0.000 & 0.000 & 0.000 & 0.000 & 0.000 & 0.000 & 0.000 & 0.001 & 0.000 & 0.000 & 0.271 & 0.000 & 0.078 \\
\hline No. obs. & 332 & 324 & 331 & 137 & 137 & 137 & 332 & 324 & 331 & 332 & 324 & 331 & 332 & 324 & 331 \\
\hline
\end{tabular}

Note: Dependent variables = percentage of temporary workers who report that they "could not find permanent job" as the main reason for temporary employment. UNEMP = unemployment rate. EP_R = OECD index for regulation of regular work. EP_T = OECD index for regulation of temporary work. EP_GAP = (EP_R-EP_T)/EP_T. Observation periods: Austria 1995-2003, 2006-08; Belgium 1985-2008; Czech Republic 1997-2008; Denmark 1985-2008; Germany 1996-2008; Finland 1995-2008; France 2003-2009; Greece 1985-2008; Hungary 1997-2008; Ireland 1985-2008; Italy 1985-2008; Netherlands 1985, 1987-2008; Norway 1995-2008 (15+), 1995-97, 2006-08 (15-24), 1995-2004, 2006-08 (25-49); Poland 2001-08; Portugal 1986-2009; Slovak Republic 1998-2008; Spain 1987-2004, 2006-08; Sweden 1995-2008; Turkey 2006-08; United Kingdom 1985-2008. Constants included but not reported. Absolute t-values within parentheses.

Source: Own calculations, based on data from Eurostat (dependent variables, UNEMP) and OECD (EP_R, EP_T, EP_GAP). 
Figure 1. Stringency of employment protection legislation in OECD countries, 19502008. Index

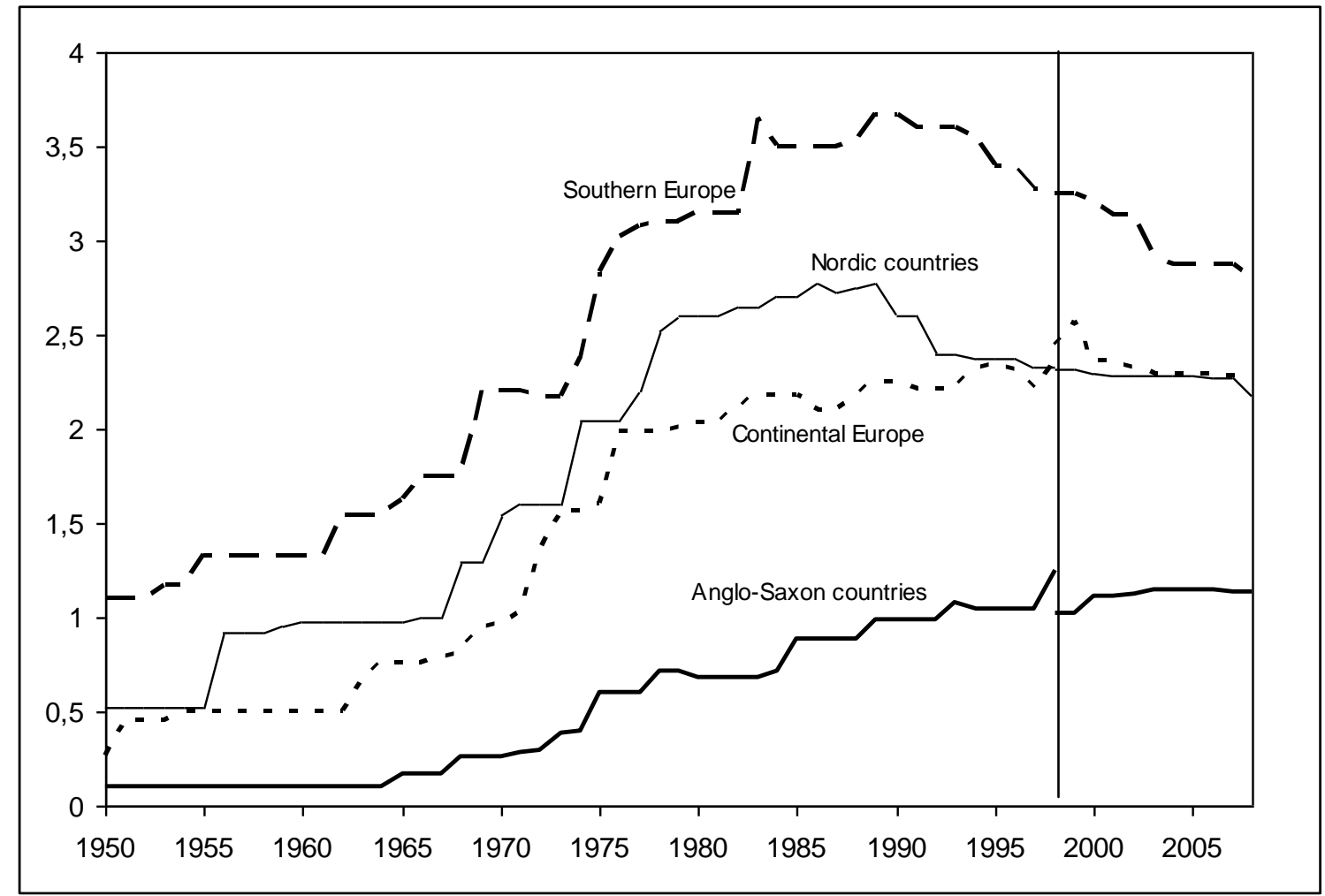

Note: The scale of the index is 0-6, where 6 represents the most stringent legislation. The series for 19982008 is based on OECD's index (version 2) for regular employment, temporary employment and collective dismissals. The series for 1950-1998 is based on OECD's index, excluding two components in regulations for regular employment, "delay to start a notice" and "compensation for unfair dismissal". The break in the two series is indicated by a vertical line. Southern Europe = Greece, Italy, Portugal and Spain. Continental Europe = Austria, Belgium, France, Germany, Netherlands and Switzerland. Anglo-Saxon countries = Australia, Canada, Ireland, New Zealand, United Kingdom and the United States. Nordic countries = Denmark, Finland, Norway and Sweden. Author's aggregation of country data, unweighted averages. Source: OECD for 1998-2008 and Allard (2005) for 1950-1998. 
Figure 2. Unemployment in OECD countries, 1960-2009. Per cent of labour force

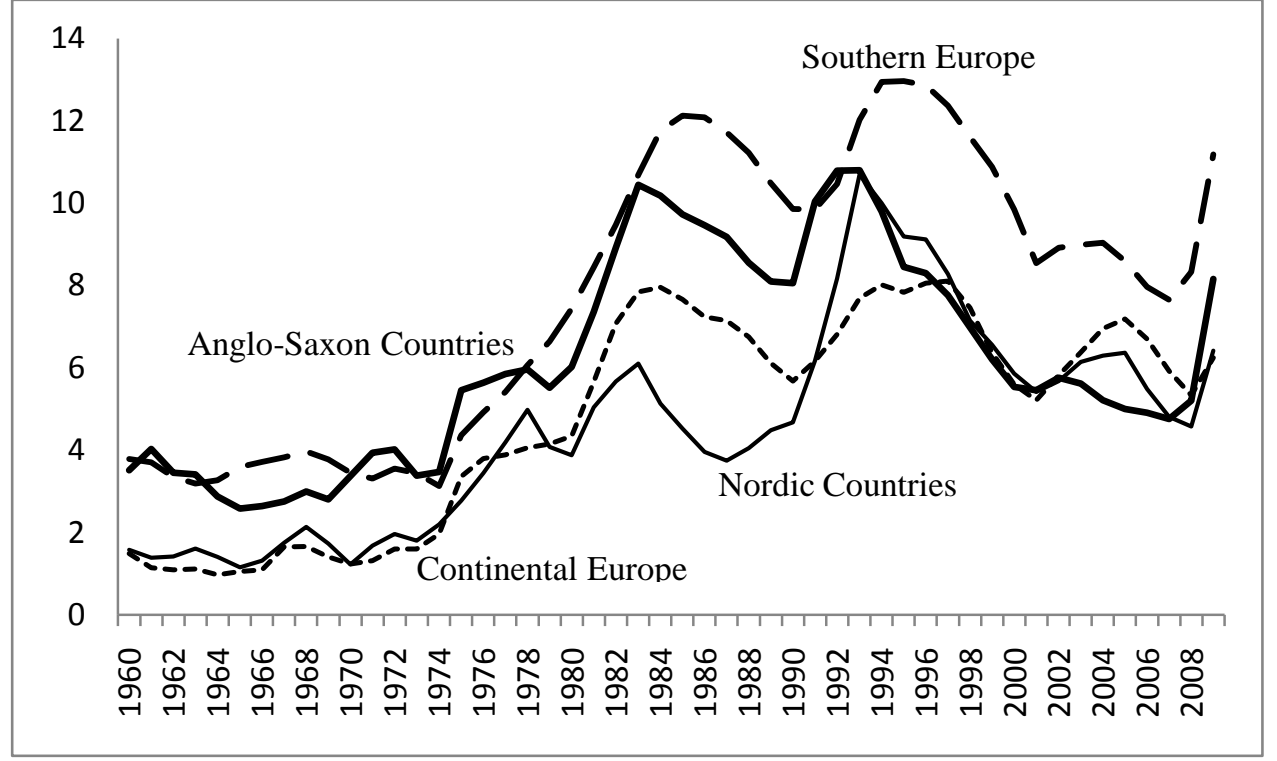

Note: See note to Figure 1 for information about the countries included and the aggregation procedure. Source: OECD. 
Figure 3.a. Reforms of employment protection legislation regarding temporary work in OECD countries

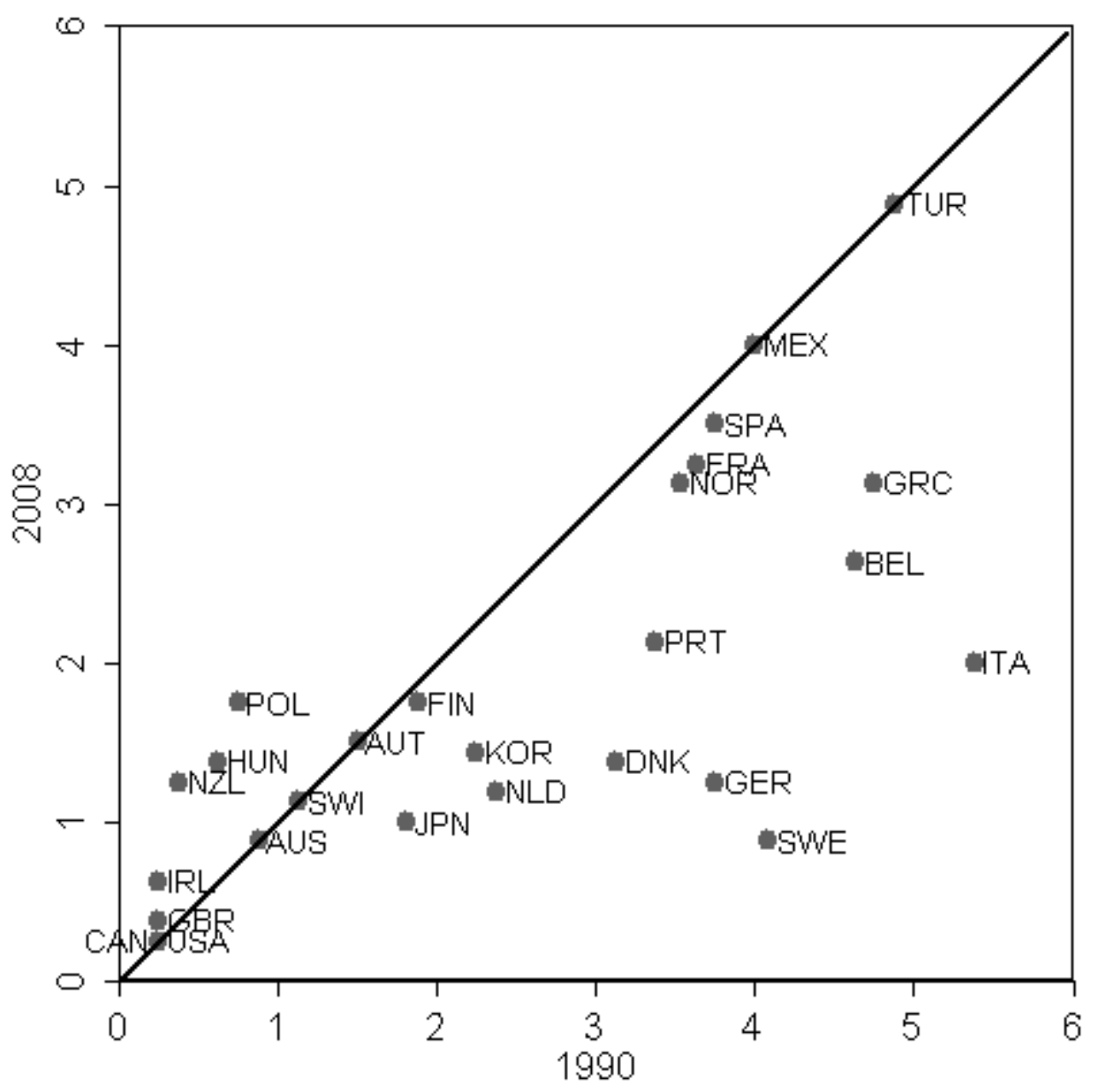

Note: The indices (version 1 of the OECD index) on the axes indicate the stringency of legislation at the respective point in time. The lower half in the figure contains those countries which liberalized legislation in the intervening period. The vertical axis refers to 2009 for France and Portugal. The positions of Canada and the United States overlap exactly.

Source: OECD. 
Figure 3.b. Reforms of employment protection legislation regarding regular work in OECD countries

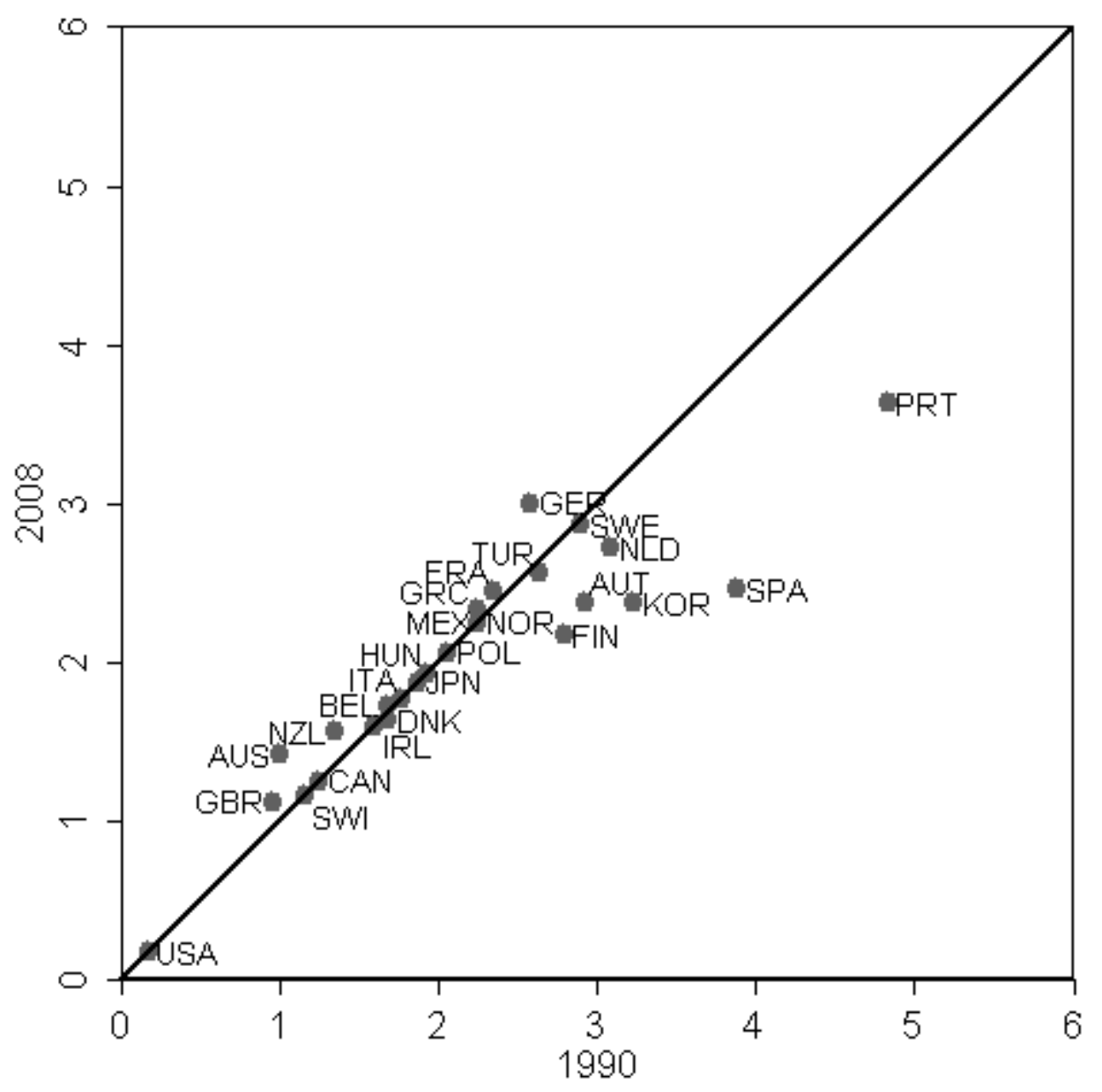

Note: See note to Figure 3.a for further details. Source: OECD. 
Figure 4. Relative youth unemployment in OECD countries, 1983-2009

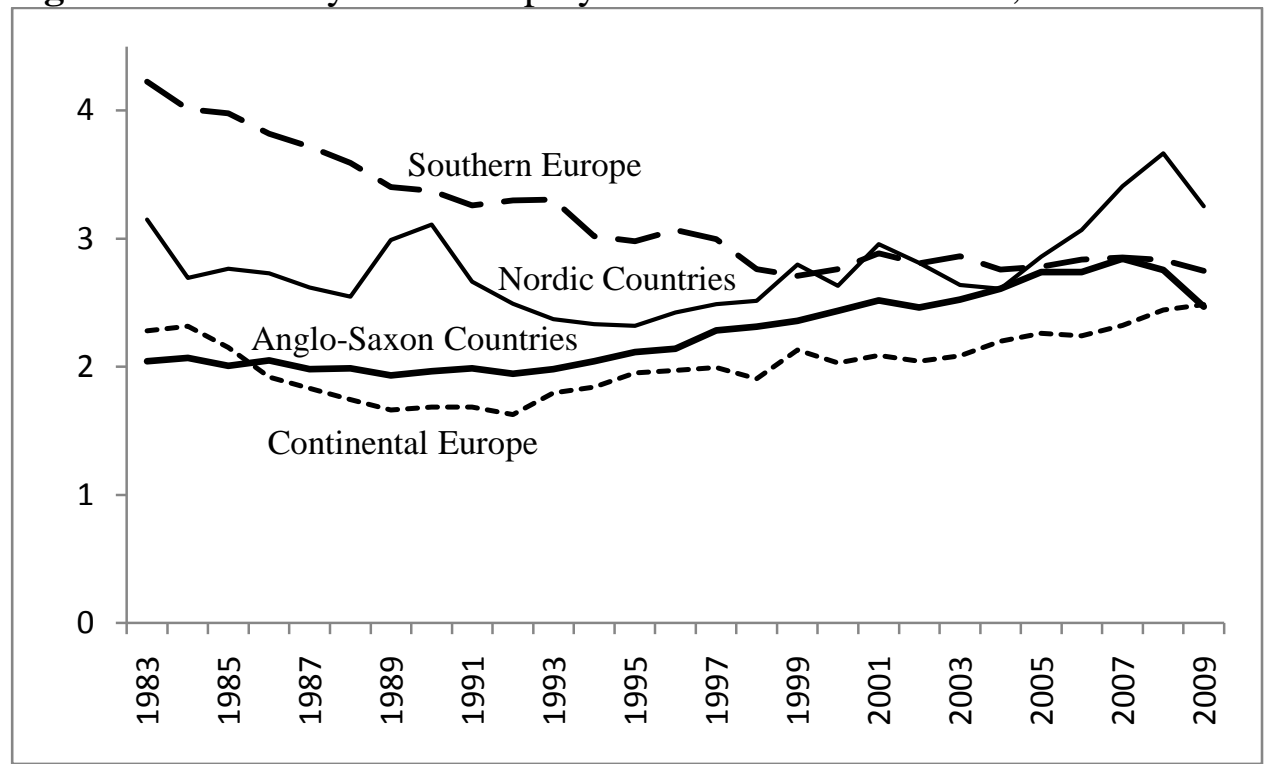

Note: Relative youth unemployment is the unemployment rate for individuals below 25 years of age relative to that of those aged 25-54 (except for Austria, where the relation is to total unemployment). New Zealand and Switzerland are excluded due to lack of data. See note to Figure 1 for information about the countries included and the aggregation procedure.

Source: OECD. 


\section{References}

Addison, J.T. and Teixeira, P. (2005), What have we learned about the employment effects of severance pay? Further iterations of Lazear et al., Empirica 32, 345-368.

Ahlberg, K., Bruun, N. and Malmberg, J. (2006), Anställningsskydd, småföretag och tillväxt, in D. Rauhut and B. Falkenhall (eds.), Arbetsrätt, rörlighet och tillväxt, Swedish Institute for Growth Policy Studies, Östersund.

Allard, G. (2005), Measuring job security over time: In search of a historical indicator for EPL (employment protection legislation), Working Paper WP05-17, Instituto de Empresa, Madrid.

Allard, G.J. and Lindert, P.H. (2007), Euro-productivity and euro-jobs since the 1960s: Which institutions really mattered?, in T.J. Hatton, K.H. O'Rourke and A.M. Taylor (eds.), The New Comparative Economic History: Essays in Honor of Jeffrey G. Williamson, MIT Press, Cambridge, MA and London.

Andersen, T.M. and Svarer, M. (2007), Flexicurity - labour market performance in Denmark, CESifo Economic Studies 53, 389-429.

Autor, D.H. (2003), Outsourcing at will: The contribution of unjust dismissal doctrine to the growth of employment outsourcing, Journal of Labor Economics 21, 1-42.

Autor, D.H., Donohue III, J.J. and Schwab, S.J. (2004), The employment consequences of wrongful-discharge laws: Large, small or none at all?, American Economic Review 94, 440-446.

Autor, D.H., Kerr, W.R. and Kugler, A.D. (2007), Does employment protection reduce productivity? Evidence from U.S. states, Economic Journal 117, F189-F217.

Baccaro, L. and Rei, D. (2007), Institutional determinants of unemployment in OECD countries: Does the deregulatory view hold water?, International Organization 61, 527-569.

Bassanini, A. and Duval, R. (2006), The determinants of unemployment across OECD countries: Reassessing the role of policies and institutions, OECD Economic Studies 42, 7-86.

Bauer, T.K., Bender, S. and Bonin, H. (2007), Dismissal protection and worker flows in small establishments, Economica 74, 804-821.

Bauernschuster, S. (2009), Relaxed dismissal protection: Effects on the hiring and firing behaviour of small firms, Jena Economic Research Paper 2009-015, Friedrich Schiller University and the Max Planck Institute of Economics, Jena.

Belot, M., Boone, J. and van Ours, J. (2007), Welfare-improving employment protection, Economica 74, 381-396.

Belot, M. and van Ours, J.C. (2004), Does the recent success of some OECD countries in lowering their unemployment rates lie in the clever design of their labor market reforms?, Oxford Economic Papers 56, 621-642.

von Below, D. and Skogman Thoursie, P. (2010), Last-in first-out? Estimating the effect of seniority rules in Sweden, Labour Economics 17, 987-997.

Bentolila, S. and Dolado, J.J. (1994), Labour flexibility and wages: Lessons from Spain, Economic Policy 9, 53-99. 
Bertola, G. (1999), Microeconomic perspectives on aggregate labor markets, in O. Ashenfelter and D. Card (eds.), Handbook of Labor Economics, vol. 3, Elsevier Science, North-Holland, Amsterdam.

Bertola, G., Blau, F.D. and Kahn, L.M. (2007), Labor market institutions and demographic employment patterns, Journal of Population Economics 20, 833-867.

Bertola, G. and Rogerson, R. (1997), Institutions and labor reallocation, European Economic Review 41, 1147-1171.

Bird, R.C. and Knopf, J.D. (2009), Do wrongful discharge laws impair firm performance?, Journal of Law and Economics 52, 197-222.

Blanchard, O. and Landier, A. (2002), The perverse effects of partial labour market reform: Fixed-term contracts in France, Economic Journal 112, F214-F244.

Blanchard, O. and Wolfers, J. (2000), The role of shocks and institutions in the rise of European unemployment: The aggregate evidence, Economic Journal 110, C1-C33.

Boeri, T. and Garibaldi, P. (2007), Two tier reforms of employment protection: A honeymoon effect?, Economic Journal 117, F357-F385.

Boeri, T. and Garibaldi, P. (2009), Beyond eurosclerosis, Economic Policy 24, 411-461.

Boeri, T. and Jimeno, J.F. (2005), The effects of employment protection: Learning from variable enforcement, European Economic Review 49, 2057-2077.

Boockmann, B., Gutknecht, D. and Steffes, S. (2008), Effects of dismissal protection legislation on individual employment stability in Germany, paper presented at the EALE conference in Amsterdam, 18-20 September 2008.

Botero, J.C., Djankov, S., La Porta, R., Lopez-de-Silanes, F. and Shleifer, A. (2004), The regulation of labor, Quarterly Journal of Economics 119, 1339-1382.

Burda, M.C. (1992), A note on firing costs and severance benefits in equilibrium unemployment, Scandinavian Journal of Economics 94, 479-489.

Cahuc, P. (2010), Employment protection legislation in Sweden, in Att skapa arbeten löner, anställningsskydd och konkurrens, SOU 2010:93, Ministry of Finance, Stockholm.

Cahuc, P. and Postel-Vinay, F. (2002), Temporary jobs, employment protection and labor market performance, Labour Economics 9, 63-91.

Calmfors, L. and Driffill, J. (1988), Bargaining structure, corporatism and macroeconomic performance, Economic Policy 3(6), 14-61.

Causa, O. and Jean, S. (2007), Integration of immigrants in OECD countries: Do policies matter?, Working Paper 564, Economics Department, OECD, Paris.

Cingano, F., Leonardi, M., Messina, J. and Pica, G. (2008), Employment protection legislation, productivity and investment: Evidence from Italy, paper presented at the EALE conference in Amsterdam, 18-20 September 2008.

Daniel, K. and Siebert, W.S. (2005), Does employment protection reduce the demand for unskilled labour?, International Economic Journal 19, 197-222.

Davis, S.J. and Haltiwanger, J. (1999), Gross job flows, in O. Ashenfelter and D. Card (eds.), Handbook of Labor Economics, vol. 3, Elsevier Science, North-Holland, Amsterdam.

Di Tella, R. and MacCulloch, R. (2005), The consequences of labour market flexibility: Panel evidence based on survey data, European Economic Review 49, 1225-1259. 
Elmeskov, J., Martin, J.P. and Scarpetta, S. (1998), Key lessons for labour market reforms: Evidence from OECD countries' experiences, Swedish Economic Policy Review 5, 205-252.

Furceri, D. and Mourougane, A. (2009), How do institutions affect structural unemployment in times of crisis?, Working Paper 730, Economics Department, OECD, Paris.

Garibaldi, P. and Violante, G.L. (2005), The employment effects of severance payments with wage rigidities, Economic Journal 115, 799-832.

Givord, P. and Maurin, E. (2004), Changes in job security and their causes: An empirical analysis for France, 1982-2002, European Economic Review 48, 595-615.

Gómez-Salvador, R., Messina, J. and Vallanti, G. (2004), Gross job flows and institutions in Europe, Labour Economics 11, 469-485.

Haltiwanger, J., Scarpetta, S. and Schweiger, H. (2006), Assessing job flows across countries: The role of industry, firm size and regulations, Discussion Paper 2450, IZA, Bonn.

Heckman, J.J. and Pagés-Serra, C. (2000), The cost of job security regulation: Evidence from Latin American labor markets, Economía 1, 109-144.

Heyman, F. and Skedinger, P. (2011), Employment protection reform, enforcement in collective agreements and worker flows, paper presented at the IAB conference "Increasing Labor Market Flexibility - Boon or Bane?" in Nuremberg, 18-19 March 2011.

Kahn, L.M. (2007), The impact of employment protection mandates on demographic temporary employment patterns: International microeconomic evidence, Economic Journal 117, F333-356.

Kahn, L.M. (2010), Employment protection reforms, employment and the incidence of temporary jobs in Europe: 1996-2001, Labour Economics 17, 1-15.

Kugler, A., Jimeno, J.F. and Hernanz, V. (2002), Employment consequences of restrictive permanent contracts: Evidence from Spanish labor market reforms, Discussion Paper 657, IZA, Bonn.

Kugler, A.D. and Pica, G. (2006), The effects of employment protection and product market regulations on the Italian labour market, in J. Messina, C. Michelacci, J. Turunen and G. Zoega (eds.), Labour Market Adjustments in Europe, Edward Elgar, Cheltenham and Northampton, MA.

Kugler, A. and Pica, G. (2008), Effects of employment protection on worker and job flows: Evidence from the 1990 Italian reform, Labour Economics 15, 78-95.

Kugler, A.D. and Saint-Paul, G. (2004), How do firing costs affect worker flows in a world with adverse selection?, Journal of Labor Economics 22, 553-584.

Lazear, E. (1990), Job security provisions and employment, Quarterly Journal of Economics 105, 699-726.

Lindbeck, A. (1993), Unemployment and Macroeconomics, MIT Press, Cambridge, MA.

Lindbeck, A. and Snower, D.J. (2001), Insiders versus outsiders, Journal of Economic Perspectives 15, 165-188.

MacLeod, B. and Nakavachara, V. (2007), Can wrongful discharge law enhance employment?, Economic Journal 117, F218-F278.

Marinescu, I. (2009), Job security legislation and job duration: Evidence from the United Kingdom, Journal of Labor Economics 27, 465-486. 
Marinescu, I. (2011), Are judges sensitive to economic conditions? Evidence from UK employment tribunals, forthcoming in Industrial and Labor Relations Review.

Martins, P. (2009), Dismissals for cause: The difference that just eight paragraphs can make, Journal of Labor Economics 27, 257-279.

Messina, J. and Vallanti, G. (2007), Job flow dynamics and firing restrictions: Evidence from Europe, Economic Journal 117, F279-F301.

Micco, A. and Pagés, C. (2006), The economic effects of employment protection: Evidence from international industry-level data, Discussion Paper 2433, IZA, Bonn.

Miles, T. (2000), Common law exceptions to employment at will and US labor markets, Journal of Law, Economics, and Organization 16, 74-101.

Nickell, S. (1997), Unemployment and labor market rigidities: Europe versus North America, Journal of Economic Perspectives 11, 55-74.

Nickell, S., Nunziata, L. and Ochel, W. (2005), Unemployment in the OECD since the 1960s. What do we know?, Economic Journal 115, 1-27.

OECD (1999), Employment Outlook, OECD, Paris.

OECD (2004), Employment Outlook, OECD, Paris.

OECD (2006), Employment Outlook, OECD, Paris.

Rönnmar, M. (2006), Den svenska arbetsrätten i internationell belysning, in D. Rauhut and B. Falkenhall (eds.), Arbetsrätt, rörlighet och tillväxt, Swedish Institute for Growth Policy Studies, Östersund.

Sá, F. (2008), Does employment protection help immigrants? Evidence from European labour markets, Discussion Paper 3414, IZA, Bonn.

Salvanes, K.G. (1997), Market rigidities and labour market flexibility: An international comparison, Scandinavian Journal of Economics 99, 315-333.

Scarpetta, S. (1996), Assessing the role of labour market policies and institutional settings on unemployment: A cross-country study, OECD Economic Studies No. 26, 43-98.

Schivardi, F. and Torrini, R. (2008), Identifying the effects of firing restrictions through sizecontingent differences in regulation, Labour Economics 15, 482-511.

Skedinger, P. (1995), Employment policies and displacement in the youth labour market, Swedish Economic Policy Review 2, 137-171.

Skedinger, P. (2010), Employment protection legislation: Evolution, effects, winners and losers, Edward Elgar, Cheltenham and Northampton, MA.

Venn, D. (2009), Legislation, collective bargaining and enforcement: Updating the OECD employment protection indicators, Working Paper 89, Directorate for Employment, Labour and Social Affairs, OECD, Paris. 